Article

\title{
Experimental Modeling of Methane Hydrate Formation and Decomposition in Wet Heavy Clays in Arctic Regions
}

\author{
Vladimir S. Yakushev \\ Department of Gas and Gas Condensate Field Development and Operation, Gubkin Russian State University of \\ Oil and Gas (National Research University), 65, Leninsky Prospekt, 119991 Moscow, Russia; \\ yakushev.v@gubkin.ru
}

Received: 13 October 2018; Accepted: 27 November 2018; Published: 27 December 2018

check for updates

\begin{abstract}
Experimental studies on clay sample saturation by methane hydrates proved that clay particles play an important role in the hydrate accumulation and decomposition processes in sediments. Depending on water content, the same clay mineral can serve as inhibitor, neutral component and promoter of hydrate formation. Wet clay is a good mineral surface for hydrate formation, but clays represent the worst media for hydrate accumulation and existence. Nevertheless, there are many observations of hydrate presence in clay-containing sediments, especially offshore. Experimental modelling of metastable hydrate decomposition in sediment samples recovered from permafrost in "Yamal crater" in the Russian Arctic has shown that metastable hydrates located in frozen, salted clays can generate huge volumes of gas, even with a negligible (tenth and hundredth of a degree) temperature rise.
\end{abstract}

Keywords: clays hydrate formation; permafrost; relic gas hydrates; gas liberations; temperature change; "permafrost pockmarks"

\section{Introduction}

It is well-known at the present time that the main volume of gas in natural gas hydrates is situated in the marine clay-enriched sediments [1]. So, in spite of the general view, that clay-enriched sediments are not permeable or are low-permeable for gas, they are a good environment for gas hydrate existence at subsea conditions. Hydrate formation in oceanic clays is usually attributed to gas generation from organic matter buried in these sediments. At the same time, some clay-enriched permafrost drill cores recovered in the Russian Arctic released great volumes of gas when thawed in warm liquid. These volumes exceeded the possible free gas volume able to be kept in pore space, indicating the presence of gas hydrates [2]. The majority of these drill cores were recovered from shallow permafrost (down to depth $150 \mathrm{~m}$ ). This means that hydrates (major component-methane 92-98\%) were metastable or relic [3,4], because the upper boundary of methane hydrate thermodynamic hydrate-stability zone in permafrost areas with hydrostatic pressure distribution in geologic section is located at a depth of 230-270 m. Metastable hydrate sensitivity to temperature changes in clay-enriched frozen sediments is not well known due to difficulties with drill core recovery and storage and with experimental production of synthetic samples.

Intra permafrost relic hydrates can occur in frozen sands as well as in loams, silks and clays. Hydrate-containing sands with metastable hydrates are modelled experimentally well enough due to good permeability of sands for water and gas (see for example [5,6]). However, experimental modeling of hydrate-saturated clay-enriched samples is a difficult task, due to the low permeability of clays for gas. There are examples of experimental study of hydrate formation and decomposition in clay 
powders and clay-water slurries (for example, [7]), but there are very few examples of experimental hydrate formation in wet, dense clay-enriched sediments, especially in a frozen state, which are spread in Arctic regions. There are even data supporting the supposition that the presence of fine (clay) particles in permeable sediments inhibits hydrate crystal growth [8]. So, the situation with methane hydrate formation, stabilization and preservation in frozen clays is very unclear. But for the natural conditions of the Arctic, mass release of greenhouse gas from permafrost zone, including frozen clays, at small temperature changes can have long-term consequences. We can expect landscape changes, atmosphere heating, active gas liberations around operating oil and gas wells, sudden gas blowouts like Yamal crater [9], gas saturation of subbotom permafrost on Arctic shelf, and so on.

\section{Experiments on Hydrate Formation/Decomposition in Heavy Wet Clays and their Results}

As is known from experiments on sand samples freezing, clay particles addition shifts freezing point to the area of low temperatures [10]. The higher the clay particle content and the lower the initial water content of a sample, the larger the temperature shift of freezing point. This is explained by the unfrozen water content increase, due to the increase in the fine particle content. So, the most remarkable temperature shift is observed in the sediments with the most fine particles-in heavy clays represented by montmorillonite (bentonite).

From this point of view, it would be interesting to study the impact of clay particles on gas hydrate formation conditions, especially at subzero temperatures. Special experiments on methane hydrate formation from fine-dispersed ice in dry clay (mineral composition-81\% montmorillonite) have been arranged in a static experimental cell to define the possibility of hydrate decomposition by dry clay particles [11]. Dried clay powder was mixed with fine-grained ice at a temperature of $-10^{\circ} \mathrm{C}$ in the proportion providing a water content of $12 \%$ of the mass-less, than the water content of maximal hygroscopity (water content of a rock sample in the 100\% air humidity atmosphere). The water content of maximal hygroscopity approximately corresponds to the water content of strongly-bonded water or unfrozen water in frozen rocks $[10,12]$. Then the prepared sample was placed into the static experimental cell, described in [11], blown through by cold methane and placed into an air freezer at a temperature of $+4{ }^{\circ} \mathrm{C}$. Methane pressure inside the cell was established as 7.0 MPa. Intensive methane hydrate formation started practically immediately after pressure establishment. This was registered by pressure reduction inside the cell (Figure 1A,B).

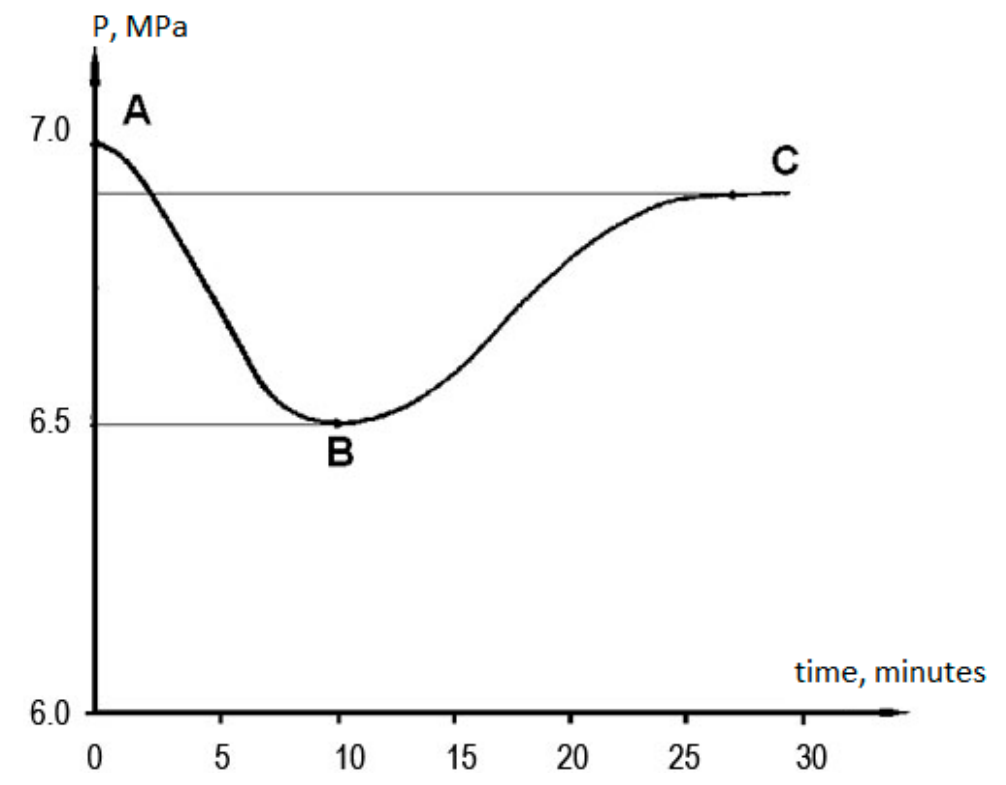

Figure 1. Pressure change with time when fine-grained ice decomposition in dry montmorillonite clay powder at hydrate formation conditions [11]. 
The initial pressure drop (Figure 1A,B) is attributed to hydrate formation from fine-grained ice. Also, there was intensive process of released water adsorption by clay particles. Point $B$ corresponds to the moment of complete disappearance of ice inside the sample. One part of the ice was transformed to hydrate, the other was adsorbed by clay. The following pressure increase (BC, Figure 1) corresponds to hydrate decomposition (at hydrate-formation conditions) and released water adsorption by clay particles. This means that clay particles with well-developed specific surface areas can inhibit hydrate formation at low water content of sediment and result in decomposition of hydrates in contact with them.

After pressure back stabilization the sample was frozen (temperature $-7^{\circ} \mathrm{C}$ ) at hydrate-formation conditions inside the cell. Then pressure was dropped to atmospheric value and the sample was extracted from the cell. Hydrate content of the sample was measured by gas content of a part of the sample when thawed in kerosene. No hydrate presence has been detected.

The extracted sample was represented by powder and was permeable for gas. Its density was about $0.5 \mathrm{~g} / \mathrm{cm}^{3}$. It was mixed with fine-grained ice again at subzero temperatures $\left(-4{ }^{\circ} \mathrm{C}\right)$ in the proportion providing water content at the upper boundary of plasticity for this sediment (according to [12]). This water content corresponds to the sum of strongly-bonded (water of inter-molecular layers and molecular surfaces, water of ion hydration) and weakly-bonded (water of poly-layers on molecular mineral surfaces, capillary and osmotic water) waters. For this sample, that value (water content of the upper boundary of plasticity) was $64 \%$ mass. The sample was placed back to the cell and hydrate-formation conditions have been re-built. Pressure inside quickly (less than $1 \mathrm{~h}$ ) reduced to the equilibrium value of hydrate formation $\left(2,3 \mathrm{MPa}\right.$ at $\left.-4{ }^{\circ} \mathrm{C}\right)$. To continue hydrate formation, additional gas has been injected into the cell a few times. After pressure stabilization at the initial value $(7.0 \mathrm{MPa})$, which indicated hydrate formation had finished, and the pressure drop, the cell was opened and the sample was extracted again. It looked like volcanic pumice cemented by hydrate micro-crystals. The specific gas content of the sample measured when thawing was about $36 \mathrm{~cm}^{3} / \mathrm{g}$, indicating great hydrate accumulation inside. This experiment has shown that strongly-bonded water practically does not form hydrates on the clay particles' surface. Weakly-bonded water is involved in the hydrate-formation process according to the degree of the system super cooling.

Later, this assumption was confirmed by experiments with methane hydrate formation in bentonite clay with volumetric water content changing in the range 2-99\% [7]. Figure 2 represents approximation of data on dependence of the super cooling degree, required for hydrate formation to start, from the water content of the sample.

The following phenomena have been observed when methane hydrate forms in bentonite clay with different water contents:

- At water content $2-10 \%$ vol. hydrate equilibrium shifted considerably to the region of low temperatures. Temperature shift sometimes exceeded $10{ }^{\circ} \mathrm{C}$ compared to the system "water-gas" (Figure 2), that is, clay acted as a hydrate inhibitor (see previous experiments with hydrate formation from clay powder and fine-grained ice);

- At water content $10-80 \%$ vol. hydrate equilibrium gradually moved to the equilibrium in the system "gas-water" and reached it at approximately $80 \%$ vol.

- At water content $80-99 \%$ vol., when there was a suspension inside the experimental cell, the hydrate formation temperature was slightly over the equilibrium temperature of the system "gas-water". This indicates the clay is a hydrate formation promoter. 


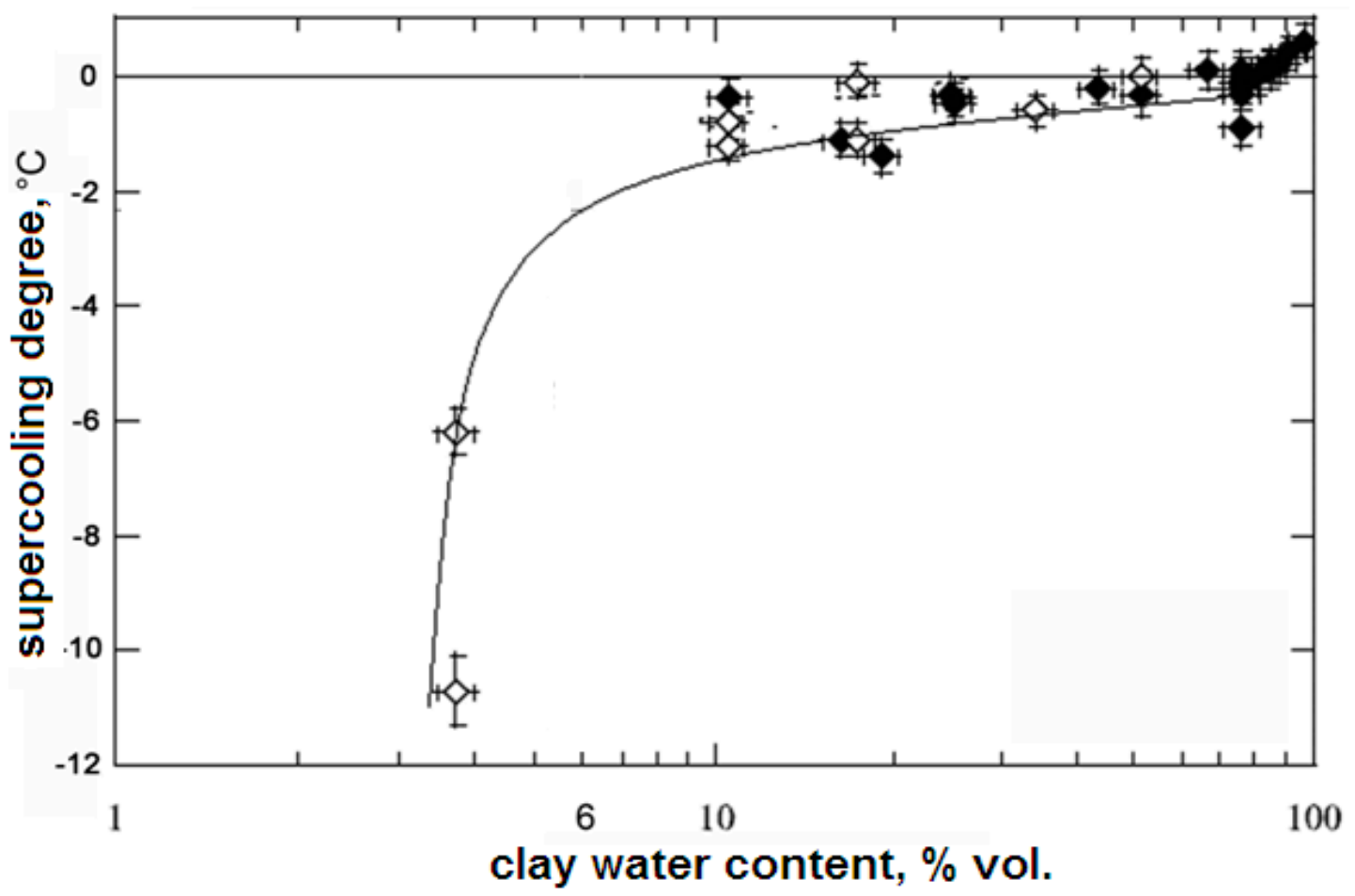

Figure 2. Shift of hydrate formation temperature in the bentonite with different water contents, comparing the equilibrium temperature in the system "methane-deionized water" (curve-approximation of data from [7].

But the most important for understanding the frozen hydrate-enriched clay's behavior with temperature change is the experiment with natural viscous mineralized clay recovered from the Yamal "ice crater" [13]. This crater was formed by a powerful water-gas blowout in the Arctic tundra [9]. Clay sediment sample was recovered from the upper part of the crater from frozen deposits of the 3rd Marine terrace of Quaternary age $\left(\mathrm{mQ}_{\mathrm{III}}{ }^{2-3}\right)$. This geologic formation continues down to the depth of 30-36 m or even $43 \mathrm{~m}$ [14].The crater geologic section is represented by Holocene organic matter-enriched brown silks (down to depth 1-1.5 m) and ice-enriched Late Quaternary $\left(\mathrm{mQ}_{\mathrm{III}}{ }^{2-3}\right.$ ) gray clays with ice content $25-50 \%$ vol. (depth $1.0-40.0 \mathrm{~m}$ ). Permafrost rock sample was taken from inner side of the crater $1.5 \mathrm{~m}$ below the day surface. According to $[15,16]$ this clay consists of montmorillonite (about $30 \%$ ) with admix of illite and kaolinite $(30 \%)$, silt $(30 \%)$, sand $(5 \%)$ and organic matter (5\%).Granulometric composition ( $60 \%$ clay fraction, 30\% silt fraction and 5\% sand fraction) corresponds to heavy clays [12]. Natural total water content of this clay is in the range $40-50 \%$ mass. The clay is salted. Salt content ( $\mathrm{Na}-\mathrm{Cl}$ type) is in the range $0.7-1.8 \%$ mass. High salinity and high clay particles content provide high content of unfrozen water-up to $15-20 \%$ at $-2.5^{\circ} \mathrm{C}$ [14]. Water content of the sample was $43 \%$ mass providing a plastic, semi-liquid state when unfrozen. The sample was packed in a plastic bag, unfrozen and transported to Moscow from the Yamal Peninsula.

The Gas Hydrate Autoclave System GHA 350 (Germany), equipped with a built-in magnetic stirrer, was used in the experiment [13]. Clay stirring was needed for maximizing the hydrate formation in the sample before freezing. The experiment consisted of sample preparation: sample drying and consequent saturation by deionized water to natural water content. This procedure provided a semi-liquid state of the sample before hydrate formation. Then the experiment proceeded to methane hydrate production in the sample, hydrate preservation after pressure drop at subzero temperatures and slow heating of the sample at a temperature below $0{ }^{\circ} \mathrm{C}$.

Pure methane $\left(\mathrm{CH}_{4} 99.99 \% \mathrm{~mol}\right)$ was used for hydrate formation. Methane was injected into the experimental cell until pressure reached $10.6 \mathrm{MPa}$, to have enough reserve of gas phase for hydrate formation. Then the magnetic stirrer inside the cell was switched on and began to rotate 
at rate of $12 \mathrm{rpm}$ (rotation per minute). The temperature of the cell was reduced from $+22{ }^{\circ} \mathrm{C}$ to $+0.65{ }^{\circ} \mathrm{C}$ over $2.5 \mathrm{~h}$. The pressure inside the cell decreased from 10.6 MPa to 8.95 MPa during this time period. The pressure decrease is attributed to methane cooling and partial hydrate formation. The sediment-water-gas system was deeply in the hydrate-stability thermodynamic region, but the stirrer continued to rotate, indicating low hydrate content. The stirrer rotation continued for another $16.5 \mathrm{~h}$ until it stopped at pressure $8.93 \mathrm{MPa}$ due to sample viscosity increase, which is attributed to hydrate cement content increase in the sample. After $0.5 \mathrm{~h}$ of staying at a temperature of $+0.65^{\circ} \mathrm{C}$ the cell began to cool down to a temperature of $-7^{\circ} \mathrm{C}$. The temperature decrease continued $4.5 \mathrm{~h}$. Pressure at the end was equal to $8.89 \mathrm{MPa}$. After that, the cell was left for $1.5 \mathrm{~h}$ to check the completion of hydrate formation inside (by pressure stabilization). No visible pressure change was observed. To transit stable hydrates to metastable (frozen) hydrates, the cell was opened and pressure was dropped to $0.002 \mathrm{MPa}$ (atmospheric pressure) at a temperature of $-6.8{ }^{\circ} \mathrm{C}$ over $1 \mathrm{~min}$. Then the autoclave was closed again. The temperature inside decreased to $-8.5{ }^{\circ} \mathrm{C}$ and then began to grow back, until it reached $-6.83{ }^{\circ} \mathrm{C}$ in $0.5 \mathrm{~h}$ due to heating from the thermos stated jacket. Pressure increased to $0.013 \mathrm{MPa}$. The pressure increase should be caused by partial decomposition of gas hydrates in the clay and their transition to a metastable, self-preserved state. The system stayed at these conditions for about $20 \mathrm{~min}$, no considerable pressure/temperature changes were observed. So, the autoclave was opened and pressure was dropped to $0.002 \mathrm{MPa}$ (atmospheric pressure) again. Then the autoclave was closed and pressure change was expected for $20 \mathrm{~min}$. The temperature inside was $-6.79{ }^{\circ} \mathrm{C}$. No pressure change has been detected. That meant the completion of the remaining hydrates' self-preservation process and their stabilization (if any hydrates still remained).

To check the reaction of self-preserved, relic hydrates in frozen mineralized clay to heating, temperature growth in the cell was established at rate of $1^{\circ} \mathrm{C}$ every $5 \mathrm{~h}$. Pressure registration inside the cell was permanent with a time interval of $2 \mathrm{~s}$. Pressure changes have been registered until the system reached a temperature of $+2{ }^{\circ} \mathrm{C}$ (certain complete ice melting and hydrate decomposition).

The slow temperature rise inside the autoclave caused irregular pressure increases. In the beginning of outer heating, when temperature inside was the same, no pressure changes registered (Figure 3A,B range), but then slow heating of the clay caused a remarkable pressure increase at a temperature of $-6.75^{\circ} \mathrm{C}$ (Figure 3B,C range). Pressure increased from $0.002 \mathrm{MPa}$ up to $0.032 \mathrm{MPa}$ over18 minutes when the temperature within the cell was stable $\left(-6.75{ }^{\circ} \mathrm{C}\right)$. So, temperature change equal to $0.04{ }^{\circ} \mathrm{C}$ caused considerable gas release from preliminary thermally stabilized clay. This can be caused only by remaining metastable hydrate decomposition on the exposed clay surface within the autoclave. Further slow temperature elevation from $-6.75{ }^{\circ} \mathrm{C}$ to $-6.57^{\circ} \mathrm{C}$ caused less intensive, but visible pressure growth from $0.032 \mathrm{MPa}$ to $0.052 \mathrm{MPa}$ (Figure 3C,D range). This pressure growth can be caused by two combined reasons: remaining metastable hydrate decomposition in the clay volume (buried inside the clay body when stirring) and some gas expansion when heating. Recalculation of pressure changes to the residual hydrate content at the beginning of heating has shown $0.3 \%$ mass content of hydrate in the clay sample. During the remaining time of the experiment, pressure increased according to the temperature increase, with no considerable deviation from the constant growth gradient until $0{ }^{\circ} \mathrm{C}$. In the temperature range $-0.7-0{ }^{\circ} \mathrm{C}$ complete clay thawing took place and clay compaction resulted in some pressure reduction. 


\section{$\mathrm{P} / \mathrm{T}$ region of intense}

\section{hydrate decomposition in}

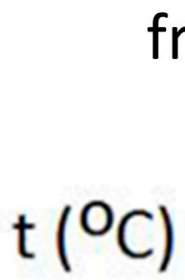

frozen clay

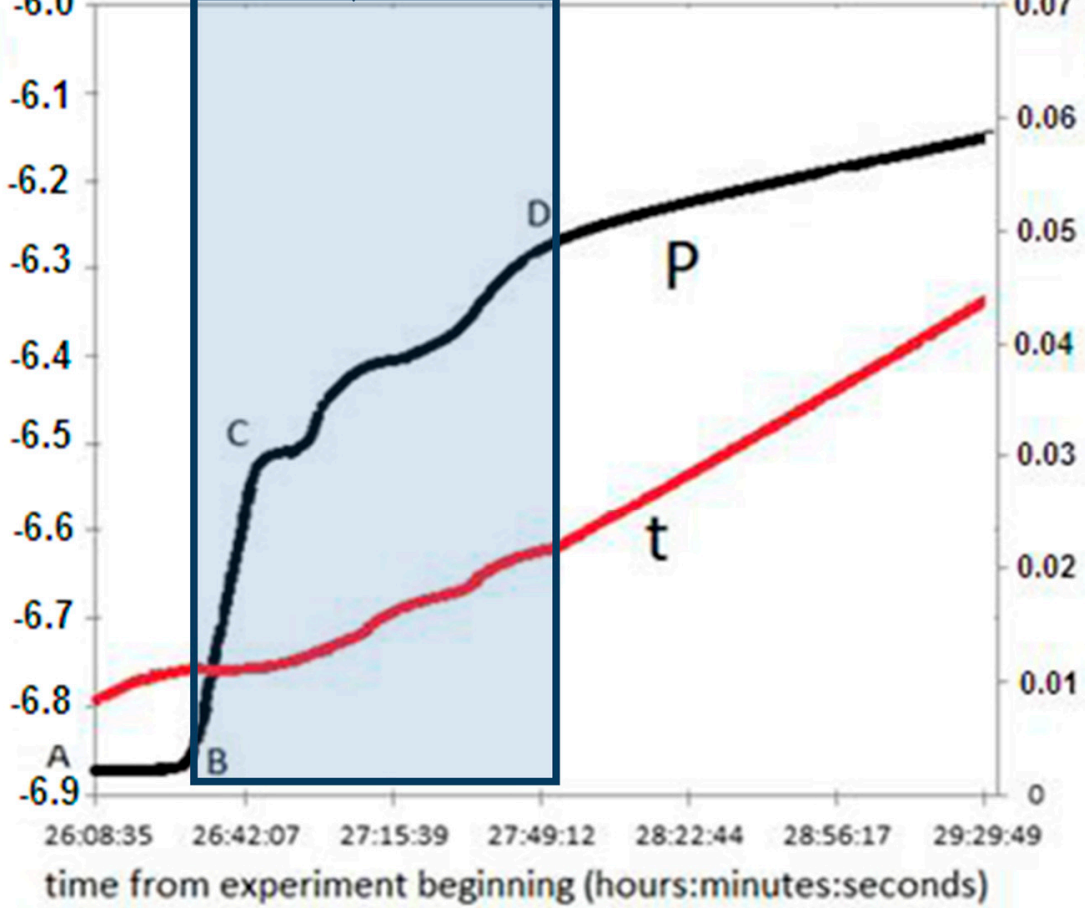

Figure 3. Experimental curves of pressure $(\mathrm{P})$ and temperature $(\mathrm{t})$ changes inside the cell when slow heating of hydrate-containing sample [13].The experiment shows, that frozen mineralized hydrate-containing clays can provide liberation of considerable volumes of gas at negligible temperature changes in permafrost section.

\section{Discussion}

The experiments listed above showed that the presence of clay particles in sediments considerably impacts on hydrate formation conditions and hydrate stability, especially at subzero temperatures. When hydrate formation takes place in heavy (bentonite or montmorillonite) clays, no hydrates form until the water content does not exceed the value of maximal hygroscopes (water content of a rock sample in a100\% air humidity atmosphere). This water content corresponds to the content of strongly-bonded water (according to E.M. Sergeev classification [12]). Further increase of water content provides favorable conditions for hydrate formation in wet clays, but much is dependent on the value of water content: deionized clay can be neutral to hydrate formation or (at high water content, water suspension) even promote hydrate formation. Salt presence in clays predictably makes hydrates inside more unstable. But when hydrate-containing salted clay sediment is frozen, stability of inner hydrates (especially metastable hydrates covered by isolating ice film) is dependent on the unfrozen and nonclathrated [17] water content, which, in its turn, is strongly dependent on subzero temperature value. Even small changes in temperature (tenths and hundredths of a degree) can cause isolating ice film damage in the pore space of hydrate-containing frozen clay and gas liberation from hydrates. One more question is: how can hydrates be formed in wet impermeable frozen clays? Of course, gas can be generated inside the sediment from buried organic matter before freezing. But also there are some reasons to assume that hydrate formation in wet clays can take place in the course of geologic section 
perennial freezing [18]. Methane solubility in water is an order greater at above zero temperatures than it is at subzero temperatures. So, the freezing front, moving down the geologic section, squeezes out former dissolved gas into pore space of freezing sediments, including clays. Being isolated in pores and surrounded by impermeable medium micro gas bubbles from former dissolved gas can form hydrates due to the all-side freezing of pore water and the local pressure increase caused by the specific water volume increase with the phase transition to ice. After the freezing front moves down, pore pressure reduces and hydrates transit to a metastable state. So, finally we have plenty of micro-inclusions of pore relic hydrates spread in huge areas of permafrost. Temperature changes on the surface of sedimentary cover (regional or local) in the offshore and continental Arctic can cause heat wave formation and penetration down the permafrost section, where even small temperature increases can activate metastable hydrates decomposition in different lithologic horizons, especially if they are salted. Processes such as thermokarst lakes formation and riverbed change can cause remarkable gas liberations from intrapermafrost metastable hydrates (Figure 4).

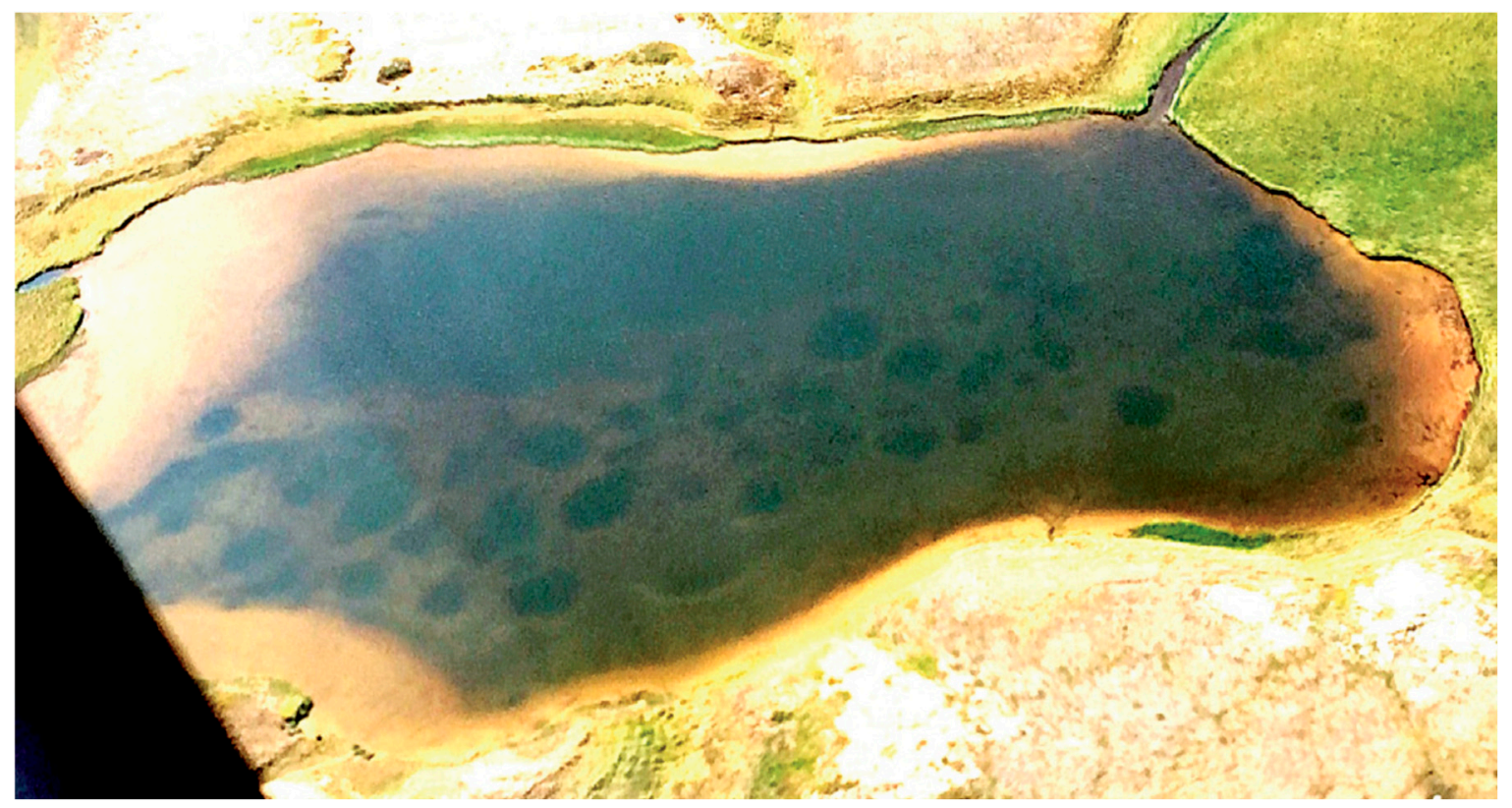

Figure 4. "Permafrost pockmarks" on Yamal thermokarst lake bottom (photo by V.I. Bogoyavlensky from helicopter).

\section{Conclusions}

Different experiments with methane hydrate formation and decomposition in wet fine clays (heavy clays) has shown that, depending on water content, clay can be a hydrate-formation inhibitor (water content 2-10\% vol. for bentonite), neutral component (water content 10-80\% vol. for bentonite), and even a hydrate-formation promoter (water content more than $80 \%$ vol. for bentonite). Hydrate formation in wet consolidated clays can take place when gas is generated inside the clay from buried organic matter or concentrated in pores from a dissolved state during sediment perennial freezing(permafrost formation). Unfrozen (and nonclathrated, according to [17]) water content of frozen clays is an important parameter for pore metastable hydrate inclusions' stability. Its content depends on sediment temperature and salinity. Even small increases of unfrozen water content due to small temperature increase can cause mass decomposition of hydrates preserved in frozen clays.

Funding: The reported study was funded by RFBR according to the research project No 18-05-70111 (Arctic Resources)

Conflicts of Interest: The author declares no conflict of interest 


\section{References}

1. Boswell, R.; Collett, T.S. Current perspectives on gas hydrate resources. Energy Environ. Sci. 2011, 4, 1206-1215. [CrossRef]

2. Yakushev, V.S. Natural Gas and Gas Hydrates in Permafrost; VNIIGAZ: Moscow, Russia, 2009; p. 192. (In Russian)

3. Yakushev, V.S. Gas hydrates in cryolithozone. Geol. Geophys. 1989, 11, 100-105. (In Russian)

4. Yakushev, V.S.; Chuvilin, E.M. Natural Gas and Gas Hydrate Accumulations within Permafrost in Russia. Cold Reg. Sci. Technol. 2000, 31, 189-197. [CrossRef]

5. Wright, J.F.; Dallimore, S.R.; Nixon, F.M. Influences of grain size and salinity on pressure-temperature thresholds for methane hydrate stability in JAPEX/JNOC/GSC Mallik 2L-38 Gas Hydrate Research Well Sediments. In Scientific Results from JAPEX/JNOC/GSC Mallik 2L-38 Gas Hydrate Research Well, Mackenzie Delta, Northwest Territories, Canada; Dallimore, S.R., Uchida, T., Collett, T.S., Eds.; Geological Survey of Canada: Ottawa, ON, Canada, 1999; Volume 544, pp. 229-240.

6. Chuvilin, E.M.; Grebenkin, S.I. Gas permeability variations in gas-filled soils upon hydrate formation and freezing: An experimental study. Earth Cryosphere 2015, 19, 59-64. [CrossRef]

7. Uchida, T.; Takeya, S.; Chuvilin, E.; Ohmura, R.; Nagao, J.; Yakushev, V.; Istomin, V.; Minagawa, H.; Ebinuma, T.; Narita, H. Decomposition of Methane Hydrates in Sand, Sandstone, Clays and Glass Beads. J. Geoph. Res. 2004, 109. [CrossRef]

8. Kumar, A.; Sakpal, T.; Roy, S.; Kumar, R. Methane hydrate formation in a test sediment of sand and clay at various levels of water saturation. Can. J. Chem. 2015, 93, 874-881. [CrossRef]

9. Bogoyavlensky, V.; Mazharov, A.; Titovsky, A.; Pushkarev, V.; Bogoyavlensky, I. Gas blowout from the permafrost zone of the Yamal-Nenets autonomous district. Arct. Herald. IV. Contemp. Probl. Arct. 2014, 4, 60-66.

10. Ershov, E.D.; Komarov, I.A.; Chuvilin, E.M.; Yakushev, V.S.; Osipov, V.I.; Buldovich, S.N.; Lebedenko, Y.P.; Cheverev, V.G.; Brouchkov, A.V.; Kuchukov, E.Z.; et al. Principles of Geocryology. Volume 1. Physico-Chemical Bases of Geocryology; Ershov, E.D., Ed.; Lanzhou University Press: Lanzhou, China, 2015; p. 297.

11. Yakushev, V.S. Composition, Structure and Properties of Frozen Hydrate-Saturated Deposits. Ph.D. Thesis, Lomonosov Moscow State University, Moscow, Russia, 1991; p. 132. (In Russian)

12. Sergeev, E.M. Soil Science. Sergeev, E.M., Ed.; Lomonosov Moscow State University: Moscow, Russia, 1983; p. 595. (In Russian)

13. Yakushev, V.S.; Semenov, A.P.; Medvedev, V.I.; Bogoyavlensky, V.I.; Bogoyavlensky, I.V. Experimental Modeling of Methane Release From Intrapermafrost Relic Gas Hydrates When Sediment Temperature Change. ColdReg. Sci. Technol. 2018, 149, 46-50. [CrossRef]

14. Chuvilin, E.M. Structure and Properties of Permafrost Rocks in South Part of Bovanenkovo Gas-Condensate Field; Chuvilin, E.M., Ed.; GEOS Publication: Moscow, Russia, 2007; p. 137. (In Russian)

15. Streletskaya, I.D.; Vasiliev, A.A.; Kanevskiy, M.Z.; Vanstein, B.G.; Shirokov, R.S. Organic carbon in the coastal quaternary sediments of the Kara Sea. Earth Cryosphere 2006, 10, 35-43. (In Russian)

16. Brushkov, A.V. Salted Permafrost Rocks of Arctic Coast, Their Genesis and Properties. Ph.D. Thesis, Lomonosov Moscow State University, Moscow, Russia, 1998; p. 331. (In Russian)

17. Istomin, V.A.; Chuvilin, E.M.; Bukhanov, B.A.; Uchida, T. Pore water content in equilibrium with ice or gas hydrate in sediments. Cold Reg. Sci. Technol. 2017, 137, 60-67. [CrossRef]

18. Yakushev, V.S. One of possible reasons of gas blowouts from permafrost. Oil Gas Geol. 1989, 4, 45. (In Russian)

(C) 2018 by the author. Licensee MDPI, Basel, Switzerland. This article is an open access article distributed under the terms and conditions of the Creative Commons Attribution (CC BY) license (http:/ / creativecommons.org/licenses/by/4.0/). 